\title{
11. The impact of increased academic standards of Proposition 16 on the graduation rates of women and men in Division IA intercollegiate athletics B. Erin Fairweather
}

\subsection{INTRODUCTION}

The academic achievement of student-athletes has been the subject of much public debate. The National Collegiate Athletic Association (NCAA) has claimed that student-athletes have an 'excellent experience' in college and that student-athletes in even the NCAA's most competitive divisions graduate at higher rates than non-athletes. If true, this implies that intercollegiate athletics actually benefit student-athletes academically (NCAA Research Staff, 2009). ${ }^{1}$ However, there is little agreement on whether intercollegiate athletics make student-athletes better-rounded individuals or whether they simply make student-athletes 'unpaid professionals' (Zimbalist, 1999).

The NCAA's implementation of Proposition 16 added to the debate, as it contradicted the NCAA's own claim that student-athletes graduate at a higher rate than the overall student population. In August 1995, Proposition 16 began to impose more-stringent academic standards for student-athletes, which raises the following question: if student-athletes were already reaching higher levels of academic achievement than the overall student population, why did the NCAA need to raise the scholastic bar for incoming freshmen?

One explanation might be that the NCAA implemented Proposition 16 for all student-athletes when in reality the NCAA was targeting specific subgroups. For example, the NCAA might have expected Proposition 16 to present a binding constraint for men, but not for women. In this chapter, I test whether Proposition 16's changes in the eligibility requirements facing student-athletes had different impacts on male and female student-athletes.

In Section 11.2, I explain Proposition 16, which implemented more rigorous academic standards for student-athletes beginning in 1995, and I present a brief review of the literature. ${ }^{2}$ In Section 11.3, I discuss the 
data, which I gathered from various sources. The data show that women have higher graduation rates than men whether or not they participate in sports. In Section 11.4, I introduce the 'difference-in-differences' (DiD) estimator as a way to test the impact of Proposition 16 on male and female student-athletes. In Section 11.5, I present the results of this estimation. While women are more likely to graduate than men, I find no evidence that Proposition 16 had a significant impact on the graduation rates of either student-athletes or non-athletes, regardless of gender. Section 11.6 concludes.

\subsection{THE NCAA's PROPOSITION 16 IN CONTEXT}

From the 1986-87 academic year through 1994-95, incoming freshman student-athletes at NCAA institutions were subject to academic eligibility requirements as laid out in Proposition $48 .^{3}$ The NCAA enacted Proposition 48 to compel prospective student-athletes to prepare for the academic rigors of college (Temkin and Young, 1990). Proposition 48 specified that students had to meet two criteria to be eligible for intercollegiate athletics and athletic grants-in-aid: they had to obtain a minimum score of 700 on their Standard Aptitude Tests (SATs) or 17 on their American College Testing (ACTs), and they had to earn a minimum 2.0 grade point average in 11 core high-school courses.

To further tighten academic requirements, the NCAA implemented Proposition 16 beginning in August 1995. Colleges phased in the higher standards in two steps in 1995-96 and 1996-97. The first cohort (1995-96) of student-athletes was required to have a 2.0 grade point average in 13 core courses in high school rather than 11, but it did not face a higher SAT/ACT requirement. The second cohort (1996-97) was subject to both the stricter course requirements and a higher SAT requirement. The revision created a 'sliding scale' in which 'a student athlete with an SAT score of 700 (ACT of 17) [needed] a GPA of at least 2.5; alternatively, a student athlete with an SAT score of 900 (ACT score of 21) [needed] a GPA of at least 2.0' (IES, 1995).

While standardized tests are highly controversial and hence draw more attention, a student's high-school course load might be a better predictor of success in college than standardized test scores (Adelman, 1999). The fact that Proposition 16 was implemented in two stages, one of which left the SAT requirements unchanged, allows me to study the effect of course requirements and SAT scores separately. I therefore separately test the impact of both stages of Proposition 16 on the graduation rates of men and women in Section 11.4. 
NCAA policies that impose stricter academic standards for studentathletes often face political resistance. Many critics claim that the more stringent standards disproportionately impact students of different races. The divisiveness of this issue was evidenced by the class action federal lawsuit brought by Cureton and Shaw (United States Court of Appeals, 1999), who argued that Proposition 16 constituted discrimination against prospective students who were African American. Their lawsuit was overturned when the Court ruled that the NCAA did not directly receive federal funds and was not subject to Title VI of the Civil Rights Act (Anderson and Hauser, 2000).

In contrast to the controversy over differential racial impacts, the differing gender impacts of such policies have received little attention despite evidence that such a difference exists. For example, a higher percentage of male than female prospective student-athletes was barred from participating in intercollegiate athletics in 1995 and 1996 for not meeting the NCAA's eligibility requirements. ${ }^{4}$ This may have occurred because male and female student-athletes have different priorities. Alternatively, the difference might reflect differences in academic talent. In either scenario, it is plausible that tighter academic standards for student-athletes create a binding constraint for men but not for women.

This chapter examines whether Proposition 16 affected male and female student-athletes differently. It therefore resembles the analysis by Amato et al. (2001), which studies the impact of Proposition 48 on the relationship between the success of a school's football program and the graduation rates of its football players. They find a negative relationship prior to Proposition 48 but no relationship after its implementation. These findings suggest that Proposition 48 imposed a binding constraint on prospective football players.

While the literature on the academic achievement of student-athletes is deep, it has yet to reach a consensus. The lack of consistency is largely due to the failure of the studies to account for unobserved heterogeneity in the sample. My use of the DiD technique accounts for this heterogeneity and provides a more reliable analysis of Proposition 16.

When examining this subject, many researchers have focused on variations in grade point average. For example, Lang and Rossi (1991) find that, for a weighted sample of Division I schools, the grade point averages of student-athletes do not differ significantly from those of the general student population, although they find that athletes are not as likely to make the Dean's List. Maloney and McCormick (1993) conclude that athletic participation has an insignificant impact on grade point average for all students except those involved in a revenue sport (that is, football and men's basketball) in-season, in which case the relationship is negative. ${ }^{5}$ 
Another measure of academic success is college graduation. Long and Caudill (1991) find that varsity athletes were more likely to graduate than their non-varsity counterparts in 1971. However, the cohort of students that they examine entered college before the enactment of Title IX, so women comprised a mere 5 percent of athletes at the time. This chapter adds to Long and Caudill by using a sample that includes a larger number of women, which allows me to contrast the academic success of athletes by gender.

Debrock et al. (1996) find that male student-athletes at successful Division I athletic programs have significantly lower graduation rates; they also find that overall graduation rates are unaffected by athletic participation. However, their sample includes only members of the women's basketball and men's football and basketball teams, which is a small percentage of the total number of student-athletes. It is not likely to be representative of all student-athletes, given that it includes only the two revenue-generating men's sports and the most popular women's sport.

Finally, Stevenson (2006: 16) finds that Title IX-induced athletic participation has a positive 'large and statistically significant effect on female educational attainment'. Unlike previous studies, such as Debrock et al., this chapter compares the graduation rates of athletes to those of nonathletes rather than the overall graduation rates. Since overall graduation rates include student-athletes, comparisons that do not separate athletes from non-athletes can be misleading. Separating the two allows me to make an unbiased comparison of the student groups.

\subsection{DATA}

Ideally, I would have performed my estimations using individual-level data, but that information is not publicly accessible. As a result, I collected university-level data for all Division IA institutions for the 2000-01, 200102 , and 2002-03 academic years. The panel dataset has as its dependent variable the graduation rates taken from the NCAA's publications. Since the graduation rates published by the NCAA are calculated by dividing the total freshman enrollment of an institution by the number of students who graduated within six years, this panel dataset uses the entering freshman classes of 1994-95, 1995-96 and 1996-97. ${ }^{6}$

The NCAA website, www.ncaa.org, provided the overall graduation rates for each member institution, as well as graduation rates for many subsets of the student population. Those graduation rates are for 'the most recent graduating class for which the required 6 years of information is 
available'. Because the first stage of Proposition 16 (hereafter 'Stage One') took effect in the 1995-96 academic year, the first cohort of students subjected to these newly implemented regulations is included in the 2001-02 graduation rates reported by the NCAA. Accordingly, the first cohort of students subjected to the second stage of Proposition 16 (hereafter 'Stage Two'), which was implemented starting in the 1996-97 academic year, are included in the NCAA's 2002-03 graduation rates. The NCAA graduation rates examined for this study do not account for the fact that students who transferred from their original college may have gone on to graduate from another institution. While the NCAA has recently addressed this issue by instituting a new methodology for calculating graduation rates, these data are not available for the period during which Proposition 16 was implemented. ${ }^{7}$

Finally, I include only universities that have Division IA football programs. $^{8}$ Institutions that support Division IA football programs, now known officially as the 'Football Bowl Subdivision', tend to have larger athletic programs. Despite their Division IA status, I excluded the US Naval Academy, the US Military Academy, and the US Air Force Academy since they do not offer scholarships based solely upon athletic ability. ${ }^{9}$

I gathered graduation rates for the total student population, graduation rates for athletes, the size of the total undergraduate population, and the total numbers of athletes from the NCAA website, and I created separate subsamples for men and women. Comparing athletes and non-athletes is more appropriate than comparing athletes and the overall student population, of which athletes are a subset. I used Bayes' theorem to calculate the graduation rates for male non-athletes and female non-athletes, which allows me to compare the outcomes of athletes and non-athletes across gender. ${ }^{10}$

While it would be useful to analyze the graduation rates for specific sports, rather than for all athletes, the data required to do so are not available. To comply with the Family Education Right and Privacy Act (FERPA), the NCAA suppresses graduation rates for subgroups that contain fewer than three students, thus generating too many empty cells to permit an analysis of individual sports. In particular, NCAA does not reveal data regarding men's and women's basketball program because of the relatively small number of players per team (Silver, 2004). ${ }^{11}$

I gathered the total number of students, the proportion of incoming freshmen who are women, and the proportion of incoming freshmen who are black from the NCAA website. I incorporate these control variables in the next section. The Chronicle of Higher Education website (www. chronicle.com) provides the following information for each of the three 
Table 11.1 Graduation rates of all students

\begin{tabular}{lcc}
\hline Type & Mean & Std dev. \\
\hline Athletes & 0.5828 & 0.1275 \\
Non-athletes & 0.5703 & 0.1682 \\
Total & 0.5775 & 0.1491 \\
\hline
\end{tabular}

Table 11.2 Graduation rates by gender

\begin{tabular}{lccccc}
\hline \multirow{2}{*}{ Gender } & \multicolumn{2}{c}{ Student athletes } & & \multicolumn{2}{c}{ Non-athletes } \\
\cline { 2 - 3 } \cline { 5 - 6 } & Mean & Std dev. & & Mean & Std dev. \\
\hline Men & 0.5125 & 0.1472 & & 0.5440 & 0.1805 \\
Women & 0.6930 & 0.1372 & & 0.6025 & 0.1669 \\
Total & 0.5828 & 0.1275 & & 0.5703 & 0.1682 \\
\hline
\end{tabular}

years of interest for men's and women's programs: number of sports teams, athletic scholarship budgets, athletic recruiting budgets, athletic program revenues, and the average salary of the head coaches.

Lastly, the Princeton Review's Complete Book of Colleges (2001, 2002, and 2003) and the College Board's College Handbook (2001, 2002, and 2003) provide profiles of the incoming freshman classes of each class considered, which includes the average ACT score of incoming freshmen. ${ }^{12}$ They also provide information regarding the athletic conference for each institution, and whether the school is a public or private school.

One argument often used by supporters of intercollegiate athletics is that the mean graduation rate for student-athletes is greater than that of the overall student population. Table 11.1 confirms this by showing that the mean institutional graduate rate for student-athletes is higher than that of the general student body and non-athletes.

When the data are separated by gender, a very different picture emerges. For example, the average graduation rate for male athletes is approximately 51 percent, 3 percentage points less than for male nonathletes and 6.5 percent less than the overall graduation rate (Tables 11.1 and 11.2). However, the average graduation rate for female athletes is 9 percent higher than that of non-athletes and 11.5 percent above the overall mean. The difference for women is statistically significant at the 1 percent level. This examination of the data suggests that there are large differences in academic achievement between men and women in Division IA athletics. 


\subsection{EMPIRICAL MODEL: THE DID ESTIMATOR}

The DiD estimator enables me to take advantage of the natural experiment that occurred when the NCAA altered the environment facing student athletes. It succeeds where other techniques fail because it avoids a trap into which more standard techniques fall. For example, one might think that one could measure the impact of Proposition 16 by running a regression of graduation rates for student-athletes over time. One would identify the impact of Proposition 16 with a dummy variable equal to one for all years after its implementation. The resulting estimates, however, could be biased because the passage of Proposition 16 might have been the result of changing attitudes toward the importance of academic performance that would have led to higher graduation rates anyway. ${ }^{13}$ Moreover, these changes in attitudes might affect the behavior of non-athletes as well so that one could mistakenly ascribe higher graduation rates among student athletes to Proposition 16 when they are actually the result of broad secular changes in attitudes and behavior.

DiD does not estimate how a treated group behaves pre- and posttreatment. Instead, it compares the change in the behavior of the treated group with the change in the behavior of an untreated group over the same period. This comparison of the two differences gives the technique its name, 'difference in differences'. Comparing the two differences also cancels the impact of unobserved characteristics on the two groups over the two time periods. (For more on DiD, see Buckley and Stang, 2003.)

DiD is a natural fit for this estimation for two reasons. First, I have data that span the years in which the NCAA enacted Proposition 16. This allows me to estimate the impact of each stage of Proposition 16's implementation. Second, since only student-athletes were subject to the NCAA's policy change, the implementation of Proposition 16 creates a natural experiment, with the non-athlete student population serving as the control group. I split the sample, running separate sets of regressions for men and women to determine whether the impact of Proposition 16 on the graduation rates of student-athletes varies by gender.

The basic DiD format for estimating the impact of Stage One of Proposition 16 (which increases only the core high-school course requirements of student-athletes) on athletes and non-athletes appears in equation (11.1):

$$
G R_{i s t}^{j}=\alpha^{j}+\lambda_{1}^{j} A_{i s}+\lambda_{2}^{j} Y R 02_{t}+\lambda_{D D}^{j}\left(A_{i s}^{*} Y R 02_{t}\right)+\varepsilon_{i s t}^{j},
$$

where $G R_{i s t}^{j}$ is the likelihood that a student of $\operatorname{sex} j(j=$ Male, Female) at institution $i$ with student-athlete status $s$ in cohort $t$ will graduate. $A_{i s}$ is 
a dummy variable equal to 1 if student $i$ is an athlete. $Y R 02_{t}$ is a dummy variable equal to 1 for the cohort that entered in 1995-96 (and should have graduated by 2001-02). $A_{i s}{ }^{*} Y R 02_{t}$ is an interaction term equal to the product of $A_{i s}$ and $Y R 02_{t}$. For example, all three variables equal one for a student who played a varsity sport and entered college in fall 1995.

It is not hard to interpret the values of the coefficients of equation (11.1). (See Angrist and Pischke (2009) for a general derivation or Leeds and McCormick (2006) for an application to the sports literature.) In particular, the constant term $\left(\alpha^{j}\right)$ is the likelihood that a non-athlete in the pre-Proposition 16 cohort graduates. $\lambda_{1}^{j}$ is the impact of being an athlete on graduating in the pre-Proposition 16 cohort. It is an alternative way of expressing the difference:

$$
\Delta_{1}=\left(G R 1_{A}^{Y r 01}-G R 1_{N}^{Y r 01}\right),
$$

where the subscript $A$ denotes student athletes and $N$ denotes nonathletes, the superscript $Y r 01$ indicates graduation by academic year 2000-01 (that is, prior to the implementation of Proposition 16), and the gender dummy is suppressed. Recall that the graduation rate for 2000-01 corresponds to the incoming class of 1994-95, and the 2001-02 rates are for the cohort that entered in 1995-96. $\lambda_{2}^{j}$ is the impact of Proposition 16 on the likelihood that a non-athlete of $\operatorname{sex} j$ would graduate, as expressed by the difference:

$$
\Delta_{N}^{1}=\left(G R 1_{N}^{Y r 02}-G R 1_{N}^{Y r 01}\right) .
$$

Finally, $\lambda_{D D}^{j}\left(\Delta_{N}^{1}\right)$ is the DiD, that is, the impact of Proposition 16 on athletes of sex $j$ minus the impact of Proposition 16 on non-athletes of the same sex:

$$
\Delta^{1}=\left(G R 1_{A}^{Y r 02}-G R 1_{A}^{Y r 01}\right)-\left(G R 1_{N}^{Y r 02}-G R 1_{N}^{Y r 01}\right) .
$$

Thus, if $\lambda_{D D}^{j}$ is statistically significant, Proposition 16 had a different impact on athletes of sex $j$ than it had on non-athletes of the same sex. Similar regressions can show the impact of Stage Two of Proposition 16 (see equations (11.7) and (11.8)).

Estimating equation (11.1) is complicated because I had data on graduation rates for institutions rather than graduation likelihoods for individual students. I therefore estimated equation (11.4) using logit regression. Card and Sullivan (1988) recommend using the logit model when the dependent variable is a probability, as this estimation framework allows the independent variables to have a nonlinear effect on the outcome. In a logit 
framework, the probability of graduating approaches 1 at a decreasing rate as the values of the explanatory variables grow. This is more reasonable than assuming that the graduation rate approaches 1 at a constant rate.

I also added a vector of control variables for the type of school to the following logits:

$$
\begin{aligned}
\ln \left(\frac{G R_{i s t}^{M}}{1-G R_{i s t}^{M}}\right)= & \alpha_{i s t}^{M}+\varphi_{1}^{\mathrm{M}} \mathbf{S C H O O L}_{i t}^{M}+\lambda_{1}^{M} A_{i s}+\lambda_{2}^{M} Y R 02_{t} \\
& +\lambda_{D D}^{M}\left(A_{i s}^{*} Y R 02_{t}\right)+\varepsilon_{i s t}^{M}, \\
\ln \left(\frac{G R_{i s t}^{F}}{1-G R_{i s t}^{F}}\right)= & \alpha_{i s t}^{F}+\varphi_{1}^{F} \mathbf{S C H O O L}_{i t}^{F}+\lambda_{1}^{F} A_{i s}+\lambda_{2}^{F} Y R 02_{t} \\
& +\lambda_{D D}^{F}\left(A_{i s}{ }^{*} Y R 02_{t}\right)+\varepsilon_{i s t}^{F},
\end{aligned}
$$

where $M$ and $F$ indicate males and females. The gender-specific $\mathbf{S C H O O L}$ vectors contain variables that control for institutional emphasis on athletics. Specifically, they are: recruiting budget, scholarship budget, average head coaching salary, athletic department revenues, presence of the men's and women's basketball teams in the NCAA basketball tournament's Sweet Sixteen (an indicator of a program's competitiveness), and whether 50 percent or more of the conference's members were invited to participate in the NCAA Basketball tournament (an indicator of the relative strength of a program's conference).

To analyze the impact of Stage Two of Proposition 16, I run the analogous logits:

$$
\begin{aligned}
\ln \left(\frac{G R_{i s t}^{M}}{1-G R_{i s t}^{M}}\right)= & \alpha_{i s t}^{M}+\varphi_{1}^{M} \mathbf{S C H O O L}_{i t}^{M}+\lambda_{1}^{M} A_{i s}+\lambda_{2}^{M} Y R 03_{t} \\
& +\lambda_{D D}^{M}\left(A_{i s}^{*} Y R 03_{t}\right)+\varepsilon_{i s t}^{M} \\
\ln \left(\frac{G R_{i s t}^{F}}{1-G R_{i s t}^{F}}\right)= & \alpha_{i s t}^{F}+\varphi_{1}^{F} \mathbf{S C H O O L}_{i t}^{F}+\lambda_{1}^{F} A_{i s}+\lambda_{2}^{F} Y R 03_{t} \\
& +\lambda_{D D}^{F}\left(A_{i s}^{*} Y R 03_{t}\right)+\varepsilon_{i s t}^{F}
\end{aligned}
$$

The indicator variable $Y R 03_{t}$ specifies the cohort, where $Y R 03_{t}=1$ if the graduation rate is for the 2002-03 academic year and $Y R 03_{t}=0$ if it is for the 2000-01 academic year. The interaction variable $\left(A_{i s} * Y R 03_{t}\right)=1$ if the graduation rate is for student-athletes in 2002-03, and 0 otherwise. Again, $\lambda_{D D}$ is the DiD estimator.

Summary statistics for all independent variables appear in Table 11.3. I expect some of the control variables - athletic recruiting budgets, 


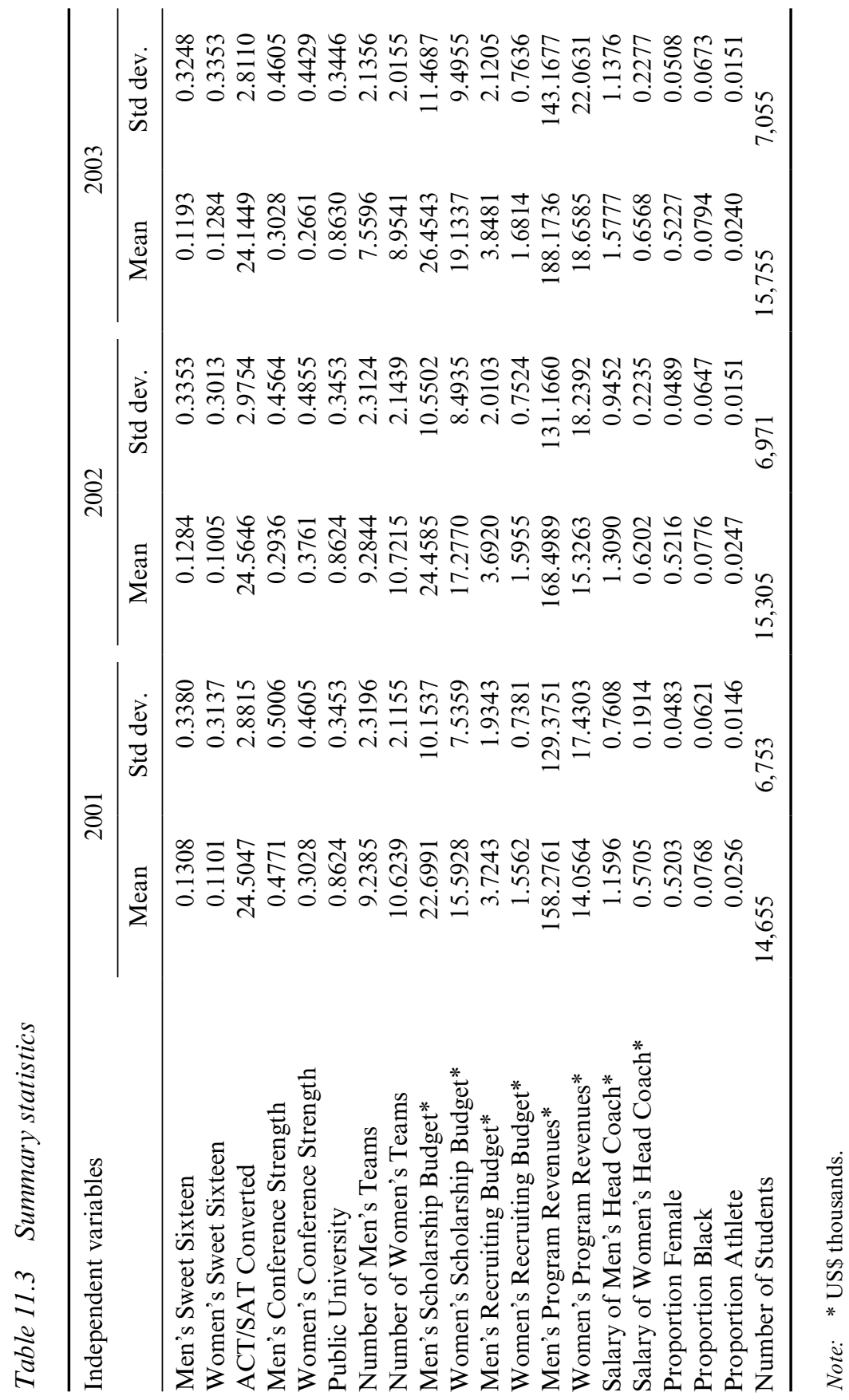


numbers of teams, proportion of students who are athletes, head coaching salaries, athletic department revenues, ${ }^{14}$ competitiveness of programs, and strengths of the conferences - to have a negative impact on graduation rates for both student-athletes and non-athletes since they indicate that resources are being invested in athletics instead of academics. For historical reasons, I also expect the proportion of students who are black to lower graduation rates of both student types. Similarly, I expect the proportion of women to increase graduation rates. Finally, I expect average ACT/SAT scores to have a positive effect on graduation rates, as higher scores are supposed to indicate greater academic aptitude.

Two control variables have no clear impact a priori. Public universities are typically less expensive than private institutions, so, ceteris paribus, public university students do not need to work as much to pay for school. However, it is also likely that public university students have less financial support from their families and have fewer academic resources than those who attend more expensive private universities. Thus, the impact of public university status on graduation rates is unclear. The second ambiguous variable is the university's student population. Although larger institutions may be able to exploit economies of scale and provide better facilities for their students, it is possible that students have better access to teachers and administrators at smaller institutions.

Finally, some control variables could push the graduation rates of student-athletes in one direction and the graduation rates of non-athletes in the other. For example, to the extent that the athletic scholarship budget indicates an institution's focus on athletics over academics, it could negatively impact the graduation rates of non-athletes. But the budget could positively impact the graduation rates of student-athletes, insofar as student-athletes feel less financial pressure if they have more scholarship funds.

\subsection{EMPIRICAL RESULTS}

Table 11.4 presents the sign and the significance of the coefficients in equations (11.5), (11.6), (11.7), and (11.8). It shows that, holding all other factors constant, the graduation rates of male student-athletes (Athlete) are significantly lower than those of male non-athletes at both stages of Proposition 16's implementation. ${ }^{15}$ In contrast, equations (11.7) and (11.8) show that the graduation rates of female student athletes (Athlete) are, all else equal, significantly higher than those of their non-athlete counterparts in both stages. These findings are all significant at the 1 percent level. Analogous OLS estimation using the DiD technique, as well as 
Handbook on the economics of women in sports

Table 11.4 Sign and significance of independent variables

\begin{tabular}{|c|c|c|c|c|}
\hline \multirow[t]{2}{*}{ Variable } & \multicolumn{2}{|c|}{ Stage One of Proposition 16} & \multicolumn{2}{|c|}{ Stage Two of Proposition 16} \\
\hline & Men & Women & Men & Women \\
\hline Athlete & Negative $(1 \%)$ & Positive $(1 \%)$ & Negative $(1 \%)$ & Positive (1\%) \\
\hline Cohort & - & - & - & - \\
\hline $\begin{array}{r}\text { Athlete \& } \\
\text { Cohort }\end{array}$ & - & - & - & - \\
\hline Sweet Sixteen & - & - & - & - \\
\hline $\mathrm{ACT} / \mathrm{SAT}$ & Positive (1\%) & Positive $(1 \%)$ & Positive $(1 \%)$ & Positive (1\%) \\
\hline $\begin{array}{l}\text { Public } \\
\text { University }\end{array}$ & Negative $(1 \%)$ & - & Negative $(5 \%)$ & - \\
\hline $\begin{array}{c}\text { Conference } \\
\text { Strength }\end{array}$ & - & - & - & - \\
\hline $\begin{array}{l}\text { Number of } \\
\text { Teams }\end{array}$ & - & - & - & - \\
\hline $\begin{array}{c}\text { Recruiting } \\
\text { Budget }\end{array}$ & Positive $(1 \%)$ & - & Positive $(1 \%)$ & Positive (1\%) \\
\hline $\begin{array}{l}\text { Program } \\
\text { Revenues }\end{array}$ & - & - & - & - \\
\hline $\begin{array}{c}\text { Scholarship } \\
\text { Budget }\end{array}$ & - & Positive $(1 \%)$ & Negative $(1 \%)$ & - \\
\hline $\begin{array}{l}\text { Salary of } \\
\text { Head Coach }\end{array}$ & Negative $(1 \%)$ & - & Negative $(1 \%)$ & - \\
\hline $\begin{array}{l}\text { Proportion } \\
\text { Female }\end{array}$ & - & - & - & - \\
\hline $\begin{array}{l}\text { Proportion } \\
\text { Black }\end{array}$ & Negative $(1 \%)$ & Negative $(1 \%)$ & Negative $(1 \%)$ & Negative $(1 \%)$ \\
\hline $\begin{array}{c}\text { Proportion } \\
\text { Athlete }\end{array}$ & Positive $(5 \%)$ & - & Positive $(5 \%)$ & - \\
\hline $\begin{array}{r}\text { Number of } \\
\text { Students }\end{array}$ & Positive (1\%) & - & Positive (1\%) & Positive $(5 \%)$ \\
\hline
\end{tabular}

cross-sectional OLS and logit regressions for each of the stages (not presented here), showed similar results. Thus, I find that there are differences in academic achievement between men and women in Division IA intercollegiate athletics, and these findings are robust to model specification.

While athletes graduate at different rates, I find no evidence that Proposition 16 had any impact on graduation rates of either studentathletes or non-athletes, regardless of gender. Both the cohort effect and the interaction effect were statistically insignificant. This implies that the reform changed neither the level of graduation rates nor the spread in graduation rates between athletes and non-athletes. 
Several of the other independent variables are statistically significant at the 1 percent and 5 percent levels. The average ACT score of incoming freshmen is positive and significant for all estimations, as expected. The proportion of students who are black has a significant, negative impact for all regressions. The size of an institution, as measured by student enrollment, is significant and positive for men in both stages and for women only in Stage Two.

The impact of the average head coach's salary in the men's athletic program is negative and significant for men but insignificant for women. The proportion of total enrollment that comprises student-athletes is significant and positive for men but insignificant for women. These two findings could be interpreted to mean that the breadth of an institution's commitment to athletics positively influences graduation rates, while its depth of commitment to one or more revenue sports negatively affects graduation rates. Also, the athletic department's recruiting budgets for men and women are positive and significant in Stage Two. Thus, I find that investment in a successful athletic program has an ambiguous impact on a university's graduation rates.

\subsection{CONCLUSION}

This chapter contributes to the literature on athletic participation and academic performance in three ways. First, it establishes that the graduation rates of female athletes at NCAA Division IA institutions are significantly higher than those of female non-athletes, while the graduation rates of male athletes are likely to be lower than those of male non-athletes. Second, the DiD technique makes it possible to leverage the natural experiment created when the NCAA implemented Proposition 16 to test the hypothesis that more rigorous academic standards impacted studentathletes at Division IA universities. Moreover, DiD eliminates potential omitted variable bias that might result from using data at the university level. My results are therefore more reliable than those of studies that do not use DiD. Third, the chapter tests the hypothesis that Proposition 16 imposed a binding constraint on men but not on women.

I find no evidence that Proposition 16 had a statistically significant impact on either male or female student-athletes. The result comes as no surprise for women, as female student-athletes graduated at a higher rate than non-athletes even before Proposition 16. The finding that Proposition 16 did not affect the relative graduation rate for men is a surprise. It might result from the fact that $I$ had to use overall graduation rates rather than graduation rates for specific sports, which are not available. This effectively 
combined the graduation rates of student-athletes in non-revenue sports, such as tennis and gymnastics, with those in the revenue sports of football and basketball, for whom Proposition 16 was intended.

Since the main argument leveled against Proposition 16 was that it would disproportionately punish black student-athletes, a natural next step would be to further subdivide the sample by race. However, given that the graduation rates of black male and female student-athletes appear to be significantly higher than the overall graduation rates of black male and female students, I do not expect Proposition 16 to have had a significant impact on either race or gender. If Proposition 16 has not had a positive impact on the graduation rates of any student-athlete subgroups, then the NCAA could have found a better use for the time and effort it spent implementing it.

\section{NOTES}

1. Dr Myles Brand's lecture notes from his speech entitled, 'Money, Motive and March Madness', which he presented March 18, 2005, at the Union League in Philadelphia when he was President of the NCAA.

2. The NCAA is divided into three Divisions based on availability of athletic scholarships, minimum number of athletic programs by gender, and so on. Proposition 16 applies only to Division I schools. I further restrict my analysis to institutions which support Division IA football programs (now known as the 'Football Bowl Subdivision'). Given that these institutions tend to involve more elaborate athletic programs, a priori one would expect the impact of Proposition 16 on these institutions to be greater. See www.ncaa.org/wps/portal/ncaahome?WCM_GLOBAL_CONTEXT=/ncaa/NCAA/ About + The + NCAA/Membership/div_criteria.html.

3. In 1983 the NCAA adopted Proposition 48, the organization's first policy which set forth minimum academic requirements for incoming freshmen student-athletes. See www.ncaa.org/wps/wcm/connect/public/NCAA/Academics/academics + history.

4. In 1995 the NCAA ruled that 4 percent of prospective female student-athletes, 5.9 percent of men in Olympic sports, and 10.5 percent of men in revenue sports were academically ineligible. The numbers rose in 1996 to 6.3 percent of females, 9.8 percent of men in Olympic sports, and 17.2 percent of men in revenue sports. See www.ncaa.org/ news/1998/19980126/active/3504n01.html.

5. The only two sports that have consistently produced positive net revenues at the Division IA level are men's football and men's basketball. Hence, these sports are known as 'revenue sports'.

6. For additional information regarding the NCAA's graduation rate calculation methodology for the relevant period, see http://fs.ncaa.org/Docs/grad_rates/2003/d1/ information.html.

7. The NCAA began publishing Graduation Success Rates (GSRs), which are calculated using a distinctly different methodology, starting in the 2004-05 academic year. GSRs have not been calculated retrospectively, and thus GSR data are available only for freshman cohorts who started college in the 1998-99 academic year and beyond. There is no a priori reason to believe that the NCAA's methodology would produce biases across gender or across time.

8. Institutions that were not classified as Division IA for both academic years of observation were also excluded. 
9. These institutions also may differ fundamentally from the other Division IA members given their status as military training grounds.

10. Bayes' theorem provides a useful formula for calculating conditional probabilities. Using Bayes' theorem, I am able to estimate the graduation rates of men and women, respectively, conditional on their being non-student-athletes. In other words, assuming that a set of men are not student-athletes, I can use Bayes' theorem to estimate their graduation rate using the data provided by the NCAA.

11. For example, see the following NCAA graduation rate report regarding the University of South Florida's 1996-97 freshman cohort, which suppresses the graduation rates for its men's and women's basketball programs, see http://usfweb2.usf.edu/assessment/ SACS $\% 202005 \% 20$ Report/reaffirmation/docs/3.3.1-64.pdf.

12. For institutions that reported only average SAT scores, I use the College Board's 2000 SAT I-ACT Score Comparison Table (2004) to convert the composite SAT score to the appropriate ACT score.

13. Alternatively, it could have been passed as a result of a growing recognition of a worsening crisis, in which case the estimates would falsely reveal a negative impact.

14. While at first glance one might expect that higher athletic department revenues would translate to more resources for the entire institution, in most cases even if the athletic department agreed to 'share the wealth', revenues garnered are too small to have a positive impact on a school's academic resources.

15. See Appendix 11A for all applicable coefficients and $p$-values for each regression.

\section{REFERENCES}

Adelman, Clifford (1999), Answers in the Tool Box: Academic Intensity, Attendance Patterns, and Bachelor's Degree Attainment, Washington, DC: United States Department of Education.

Amato, Louis H., John M. Gandar and Richard A. Zuber (2001), 'The Impact of Proposition 48 on the Relationship between Football Success and Football Player Graduation Rates', Journal of Sport Economics, 2(2), May: 101-12.

Anderson, Paul M. and Kirsten Hauser (eds) (2000), 'Third Circuit Holds NCAA Is Not Subject to Title VI', You Make the Call ..., 2(3), Winter, online at: http://sports.findlaw. com/sports_law/makethecall/winter2000/cure/index.html (accessed February 18, 2012).

Angrist, Joshua D. and Jörn-Steffen Pischke (2009), Mostly Harmless Econometrics: An Empiricist's Companion, Princeton, NJ: Princeton University Press.

Buckley, Jack and Yi Shang (2003), 'Estimating Policy and Program Effects with Observational Data: The Differences-in-Differences Estimator', Practical Assessment, Research and Evaluation, online at: www.pareonline.net/Home.htm (accessed November 3, 2004).

Card, David and Daniel Sullivan (1988), 'Measuring the Effect of Subsidized Training Programs on Movements in and out of Employment', Econometrica, 56(3), May: 497-530.

'College Board 2000 SAT I-ACT Score Comparisons Table' (2004), online at: www.collegeboard.com/sat/cbsenior/html/stat00f.html (accessed November 19, 2004).

College Handbook (2001), New York: The College Board.

College Handbook (2002), New York: The College Board.

College Handbook (2003), New York: The College Board.

Complete Book of Colleges (2001), The Princeton Review, New York: Random House.

Complete Book of Colleges (2002), The Princeton Review, New York: Random House.

Complete Book of Colleges (2003), The Princeton Review, New York: Random House.

Debrock, Lawrence, Wallace Hendricks and Roger Koenker (1996), 'The Economics of Persistence: Graduation Rates of Athletes as Labor Market Choice', Journal of Human Resources, 31(3), Summer: 299-306.

Institute of Education Sciences (IES): National Center for Education Statistics (1995), 'Who 


\section{Handbook on the economics of women in sports}

Can Play? An Examination of NCAA's Proposition 16', Statistics in Brief, Washington DC: US Department of Education, online at: nces.ed.gov/pubs/web/95763.asp (accessed January 10, 2012).

Lang, Eric L. and Robert J. Rossi (1991), 'Understanding Academic Performance: 1987-1988 National Study of Intercollegiate Athletes', paper presented at the Annual Meeting of the American Research Association, Chicago, IL, April 3-7.

Leeds, Michael A. and Barbara Erin McCormick (2006), 'Econometric Issues in Sports Economics', in Handbook of Sports Economics Research, edited by J. Fizel, Armonk, NY: M.E. Sharpe, pp. 221-36.

Long, James E. and Steven B. Caudill (1991), 'The Impact of Participation in Intercollegiate Athletics on Income and Graduation', Review of Economics and Statistics, 73(3), August: $525-31$.

Maloney, Michael T. and Robert E. McCormick (1993), 'An Examination of the Role that Intercollegiate Athletic Participation Plays in Academic Achievement: Athletes' Feats in the Classroom', Journal of Human Resources, 28(3), Summer: 555-70.

NCAA Research Staff (2009), 'NCAA Research Related to Graduation Rates of Division I Student-Athletes 1984-2002', NCAA Research, November, online at: www.ncaa.org/ wps/wcm/connect/babb88004058023db423b5a8eaf4dbca/Federal+Graduation+Rates + Summary+19+Year+11_09.pdf?MOD=AJPERES\&CACHEID = babb88004058023db4 23b5a8eaf4dbca (accessed January 10, 2012).

Silver, Rebecca (2004), 'Daniel McQuade: Colleges Fail Their Basketball Players', The Daily Pennsylvanian, April, online at: http://www.thedp.com/index.php/article/2004/04/ daniel_mcquade_colleges_fail_their_basketball_players.

Stevenson, Betsey (2006), 'Beyond the Classroom: Using Title IX to Measure the Return to High School Sports', Wharton Business School Working Paper, Philadelphia, PA, March.

Temkin, Barry and Linda Young (1990), 'Prop 48 Gets Mixed Grades: Athletes Paying More Attention', Chicago Tribune, October, online at: http://articles.chicagotribune.com/199010-19/sports/9003290394_1_force-athletes-scholastic-aptitude-test-american-college-test.

United States Court of Appeals, Third Circuit (1999), Cureton v. National Collegiate Athletic Association, No.99-1222, December, online at: http://www.caselaw.findlaw.com/us-3rdcircuit/1116586.html (accessed January 11, 2012).

Zimbalist, Andrew (1999), Unpaid Professionals: Commercialism and Conflict in Big-Time College Sports, Princeton, NJ: Princeton University Press. 
APPENDIX 11A

Table 11A.1 Stage One Proposition 16-men's program estimates differences-in-differences logit

\begin{tabular}{lcccc}
\hline Variable & $\begin{array}{c}\text { Parameter } \\
\text { estimate }\end{array}$ & $\begin{array}{c}\text { Standard } \\
\text { error }\end{array}$ & $\begin{array}{c}\text { Wald } \\
\text { Chi-square }\end{array}$ & Pr $>$ ChiSq \\
\hline Athlete & -0.6735 & 0.2407 & 7.8262 & 0.0051 \\
Cohort & 0.1890 & 0.2439 & 0.6003 & 0.4384 \\
Athlete \& Cohort & 0.0553 & 0.3390 & 0.0266 & 0.8705 \\
Sweet Sixteen & -0.2540 & 0.2643 & 0.9239 & 0.3365 \\
ACT/SAT & 0.4082 & 0.0495 & 67.9207 & $<0.0001$ \\
Public University & -0.7026 & 0.2651 & 7.0234 & 0.0080 \\
Conference Strength & 0.0950 & 0.1878 & 0.2559 & 0.6130 \\
Number of Teams & -0.0117 & 0.0523 & 0.0498 & 0.8234 \\
Recruiting Budget & 0.1038 & 0.0149 & 48.5997 & $<0.0001$ \\
Program Revenues & 0.0714 & 0.0743 & 0.9224 & 0.3368 \\
Scholarship Budget & -0.00196 & 0.00113 & 2.9978 & 0.0834 \\
Salary of Head Coach & -0.5043 & 0.1305 & 14.9328 & 0.0001 \\
Proportion Female & 0.1198 & 2.0037 & 0.0036 & 0.9523 \\
Proportion Black & -6.1060 & 1.5106 & 16.3396 & $<0.0001$ \\
Proportion Athlete & 24.0868 & 9.6311 & 6.2547 & 0.0124 \\
Number of Students & 0.000059 & 0.000022 & 7.2886 & 0.0069 \\
\hline
\end{tabular}

Table 11A.2 Stage One Proposition 16-women's program estimates differences-in-differences logit

\begin{tabular}{lcccr}
\hline Variable & $\begin{array}{c}\text { Parameter } \\
\text { estimate }\end{array}$ & $\begin{array}{c}\text { Standard } \\
\text { error }\end{array}$ & $\begin{array}{c}\text { Wald } \\
\text { Chi-square }\end{array}$ & Pr $>$ ChiSq \\
\hline Athlete & 1.7440 & 0.2490 & 49.0697 & $<0.0001$ \\
Cohort & 0.2632 & 0.2420 & 1.1828 & 0.2768 \\
Athlete \& Cohort & -0.5580 & 0.3393 & 2.7050 & 0.1000 \\
Sweet Sixteen & 0.3596 & 0.2866 & 1.5746 & 0.2095 \\
ACT/SAT & 0.4892 & 0.0496 & 97.4273 & $<0.0001$ \\
Public University & 0.2078 & 0.3293 & 0.3983 & 0.5280 \\
Conference Strength & -0.0136 & 0.2104 & 0.0042 & 0.9484 \\
Number of Teams & -0.0167 & 0.0604 & 0.0769 & 0.7815 \\
Recruiting Budget & -0.1677 & 0.1719 & 0.9518 & 0.3293 \\
Program Revenues & -0.00266 & 0.00531 & 0.2512 & 0.6163 \\
Scholarship Budget & 0.0860 & 0.0197 & 19.1124 & $<0.0001$ \\
Salary of Head Coach & -0.9279 & 0.5326 & 3.0354 & 0.0815 \\
Proportion Female & -0.6206 & 2.0370 & 0.0928 & 0.7606 \\
Proportion Black & -4.3323 & 1.4980 & 8.3645 & 0.0038 \\
Proportion Athlete & 17.9362 & 9.8773 & 3.2975 & 0.0694 \\
Number of Students & 0.000038 & 0.000020 & 3.4833 & 0.0620 \\
\hline
\end{tabular}


Table 11A.3 Stage One Proposition 16-men's program estimates differences-in-differences logit

\begin{tabular}{lccrr}
\hline Variable & $\begin{array}{c}\text { Parameter } \\
\text { estimate }\end{array}$ & $\begin{array}{c}\text { Standard } \\
\text { error }\end{array}$ & $\begin{array}{c}\text { Wald } \\
\text { Chi-square }\end{array}$ & Pr $>$ ChiSq \\
\hline Athlete & -0.6972 & 0.2408 & 8.3810 & 0.0038 \\
Cohort & 0.00727 & 0.2735 & 0.0007 & 0.9788 \\
Athlete \& Cohort & 0.2274 & 0.3367 & 0.4560 & 0.4995 \\
Sweet Sixteen & -0.2024 & 0.2702 & 0.5612 & 0.4538 \\
ACT/SAT & 0.4348 & 0.0513 & 71.8049 & $<0.0001$ \\
Public University & -0.5887 & 0.2524 & 5.4409 & 0.0197 \\
Conference Strength & 0.1994 & 0.1963 & 1.0325 & 0.3096 \\
Number of Teams & 0.0183 & 0.0545 & 0.1127 & 0.7371 \\
Recruiting Budget & 0.1084 & 0.0142 & 58.5392 & $<0.0001$ \\
Program Revenues & 0.1412 & 0.0740 & 3.6374 & 0.0565 \\
Scholarship Budget & -0.00383 & 0.00119 & 10.2990 & 0.0013 \\
Salary of Head Coach & -0.3144 & 0.1060 & 8.7923 & 0.0030 \\
Proportion Female & 2.0158 & 1.9588 & 1.0591 & 0.3034 \\
Proportion Black & -7.2918 & 1.4912 & 23.9115 & $<0.0001$ \\
Proportion Athlete & 18.4594 & 8.7373 & 4.4635 & 0.0346 \\
Number of Students & 0.000052 & 0.000021 & 6.3004 & 0.0121 \\
\hline
\end{tabular}

Table 11A.4 Stage One Proposition 16-women's program estimates DiD logit

\begin{tabular}{lccrr}
\hline Variable & $\begin{array}{c}\text { Parameter } \\
\text { estimate }\end{array}$ & $\begin{array}{c}\text { Standard } \\
\text { error }\end{array}$ & $\begin{array}{c}\text { Wald } \\
\text { Chi-square }\end{array}$ & Pr $>$ ChiSq \\
\hline Athlete & 1.8208 & 0.2496 & 53.2102 & $<0.0001$ \\
Cohort & 0.1912 & 0.2848 & 0.4510 & 0.5019 \\
Athlete \& Cohort & -0.3315 & 0.3361 & 0.9729 & 0.3240 \\
Sweet Sixteen & 0.4103 & 0.2825 & 2.1101 & 0.1463 \\
ACT/SAT & 0.4927 & 0.0499 & 97.6265 & $<0.0001$ \\
Public University & -0.1080 & 0.2708 & 0.1591 & 0.6900 \\
Conference Strength & 0.2254 & 0.2161 & 1.0878 & 0.2970 \\
Number of Teams & 0.0322 & 0.0606 & 0.2831 & 0.5947 \\
Recruiting Budget & 0.0759 & 0.0174 & 19.1219 & $<0.0001$ \\
Program Revenues & -0.2217 & 0.1943 & 1.3020 & 0.2538 \\
Scholarship Budget & -0.00081 & 0.00453 & 0.0319 & 0.8582 \\
Salary of Head Coach & -0.9395 & 0.5950 & 2.4931 & 0.1143 \\
Proportion Female & -0.6835 & 2.0919 & 0.1068 & 0.7439 \\
Proportion Black & -6.0819 & 1.5003 & 16.4321 & $<0.0001$ \\
Proportion Athlete & 16.2725 & 8.8423 & 3.3867 & 0.0657 \\
Number of Students & 0.000039 & 0.000020 & 3.9185 & 0.0478 \\
\hline
\end{tabular}

